\title{
Observations of Ash, Ice, and Lightning within Pyrocumulus Clouds Using Polarimetric NEXRAD Radars and the National Lightning Detection Network
}

\author{
KENDELL T. LAROCHE ${ }^{\mathrm{a}}$ \\ Department of Atmospheric Sciences, University of North Dakota, Grand Forks, North Dakota \\ TIMOTHY J. LANG \\ NASA Marshall Space Flight Center, Huntsville, Alabama
}

(Manuscript received 2 September 2017, in final form 27 October 2017)

\begin{abstract}
A pyrocumulus is a convective cloud that can develop over a wildfire. Under certain conditions, pyrocumulus clouds become vertically developed enough to produce lightning. NEXRAD dual-polarization weather radar and upgraded National Lightning Detection Network (NLDN) data were used to analyze 10 case studies of ash plumes and pyrocumulus clouds from 2013 that either did or did not produce detected lightning. Past research has shown that pyrocumulus cases are most likely to produce lightning when there is a decrease in differential reflectivity (toward $0 \mathrm{~dB}$ ) and an increase in the correlation coefficient (to $>0.8$ ), as measured by polarimetric radar, due to the transition from pure smoke/ash to frozen hydrometeors. All pyrocumulus cases that produced lightning in this study displayed the polarimetric characteristics of rimed ice within their respective clouds. Time series analysis of radar-inferred ash and rimed ice volumes within ash plumes and pyrocumulus clouds showed that NLDN-detected lightning occurred only after the cloud contained significant amounts of precipitation-sized rimed ice. The results suggest that the recently dual-pol-enabled NEXRADs and the more sensitive NLDN network can be used to explore ash plume and pyrocumulus microphysical structure and lightning production.
\end{abstract}

\section{Introduction}

Wildfires are a major concern around the world, and can threaten lives, property, and wilderness. Pyrocumulus (PyroCu) clouds are convective clouds that form above a fire during its rapid growth, or under favorable atmospheric conditions (Johnson et al. 2014; Lareau and Clements 2016; Peterson et al. 2017b). PyroCu clouds, particularly in their deepest and most intense form [Pyrocumulonimbus (PyroCb)], can inject significant amounts of smoke and ash as high as the lower stratosphere, impacting the chemical composition and aerosol concentration in the upper atmosphere (Fromm et al. 2005, 2010; Rosenfeld et al. 2007; Peterson et al. 2017b).

The transition from smoke/ash to PyroCu or PyroCb clouds can be difficult to determine using conventional,

\footnotetext{
${ }^{a}$ Current affiliation: South Texas Weather Modification Association, Pleasanton, Texas.
}

Corresponding author: Timothy J. Lang, timothy.j.lang@nasa. gov nonpolarimetric radars, as ash particles are large enough to be observed by S-band and higher-frequency weather radars (Melnikov et al. 2008, 2009; Jones et al. 2009). Lang et al. (2014) showed that polarimetric radar was extremely valuable for distinguishing between ash and rimed ice in these clouds, through the use of reflectivity $Z_{\mathrm{H}}$, differential reflectivity $Z_{\mathrm{DR}}$, and correlation coefficient $\rho_{\mathrm{HV}}$.

Sufficiently developed pyro-clouds have been observed to produce lightning (Latham 1991; Fernandes et al. 2006; Rosenfeld et al. 2007; Lang et al. 2014; Dowdy et al. 2017). Lightning most commonly forms from charge separation caused by collisions between ice particles in the presence of supercooled liquid water within strong updrafts (Takahashi 1978; Takahashi and Miyawaki 2002). First lightning is generally preceded by a reduction in $Z_{\mathrm{DR}}$ values to near $0 \mathrm{~dB}$, reflecting the development of rimed ice and thus electrification (Mattos et al. 2017). Lightning in pyro-clouds can be either intracloud (IC) or cloud-to-ground (CG), and can have positive or negative polarity, with most CG lightning $(\geq 90 \%)$ transferring a negative change to the 
ground (Orville and Silver 1997; Lang and Rutledge 2002). Flashes with peak currents below $10 \mathrm{kA}$ typically are ICs, while those above $20 \mathrm{kA}$ are generally CGs, with the intermediate range of 10-20 kA comprising a mixture of ICs and CGs (Biagi et al. 2007).

Analysis of multiple Colorado cases during 2012 found that PyroCb clouds containing radar-inferred rimed ice particles produced lightning, while ash plumes or PyroCu clouds containing little ice did not produce lightning (Lang et al. 2014). However, their $Z_{\mathrm{H}}$ observations often were low for rimed ice $(<30 \mathrm{dBZ})$, based on past research in conventional storms (Smith 1984; Vivekanandan et al. 1999).

High aerosol concentrations may have been the cause of the low $Z_{\mathrm{H}}$ values for rimed ice in the Colorado cases. Rosenfeld et al. (2007) described how high concentrations of aerosols suppress precipitation in clouds, which leads to supercooled water at higher altitudes. High aerosol concentrations delay the formation of graupel (Reutter et al. 2014) and cause its average density to decrease (Mansell and Ziegler 2013). This lower-density graupel would produce smaller $Z_{\mathrm{H}}$, and exist at higher altitudes, potentially explaining the observations of Lang et al. (2014).

This paper is motivated by three issues stemming from the limitations of the Lang et al. (2014) study:

- The lightning and microphysical structures observed in Colorado during 2012 were very unusual compared to conventional thunderstorms. Are comparable observations seen in PyroCu elsewhere?

- Lang et al. (2014) used a single research polarimetric radar. To study the radar structures of PyroCu across the entire United States requires the use of the NEXRAD radar network. Fortuitously, this network was recently upgraded to become polarimetric (Cunha et al. 2015). Can dual-pol NEXRADs document the internal microphysical structures of PyroCu nationwide, especially in distinguishing rimed ice from ash?

- The lightning in the 2012 Colorado PyroCb was studied using a regional lightning network with high detection efficiency. A major nationwide lightning network, the National Lightning Detection Network (NLDN), detected no lightning in the 2012 Colorado cases, likely because the flashes were weak ICs (i.e., peak current $<5-10 \mathrm{kA}$ ). However, the NLDN was upgraded to become significantly more sensitive after 2012, with IC detection efficiency determined to be as high as 50\% (Murphy and Nag 2015). Can it now observe weak pyro-cloud ICs?

For this study, ash plumes and PyroCu clouds that either did or did not produce lightning were examined. The results show the value added by upgraded NEXRAD and NLDN observations for studying PyroCu electrification, and provide additional evidence that PyroCu do not produce lightning unless significant ice is present.

\section{Data and methodology}

\section{a. Data sources}

The 10 wildfire events ( 12 case days in total) examined in this study are listed in Table 1. All occurred during June-August 2013 in the western United States, and included a wide range of acreage burned, destructiveness to human infrastructure, and loss of human life. Basic information about these events was gathered from a variety of sources such as social media articles, GOES-15 satellite image and dataset archives, news reports, and web pages dedicated to tracking wildfire and pyro-cloud events (in particular, https://inciweb. nwcg.gov/ and http://pyrocb.ssec.wisc.edu/). This information was used to determine whether a PyroCb cloud occurred during each case.

This project used Level-II dual-pol NEXRAD data. The nationwide dual-pol upgrade was completed before the occurrence of the wildfire cases examined in this study. The closest radar that provided the most complete scan coverage for each wildfire event was selected via inspection. In all but three cases, the closest NEXRAD was over $100 \mathrm{~km}$ away, so care was taken when interpreting the radar measurements, due to reduced spatial resolution and nonuniform beamfilling at these distances (Smith et al. 1996). Level-III NEXRAD Enhanced Echo Top products were also analyzed for each case.

Lightning flash data were obtained from the NLDN. The lightning data contained the latitude-longitude locations, polarity, and flash classification (IC or CG). After 2012 the NLDN was upgraded to become more sensitive. Murphy and Nag (2015) determined that the IC detection efficiency was raised from $\sim 25 \%$ to $\sim 50 \%$ following the upgrade. The CG detection efficiency is $\sim 95 \%$ and location accuracy is better than $500 \mathrm{~m}$ (Cummins and Murphy 2009).

\section{b. Methods}

Analysis focus was placed on the $Z_{\mathrm{H}}, Z_{\mathrm{DR}}$, and $\rho_{\mathrm{HV}}$ parameters, similar to Lang et al. (2014). Under Rayleigh conditions with radar wavelength much greater than particle size, $Z_{\mathrm{H}}$ is related to the sixth moment of particle diameters (Rinehart 2010). The term $Z_{\mathrm{DR}}$ is the reflectivity-weighted mean axis ratio in the horizontal and vertical directions (Rinehart 2010). The correlation coefficient $\rho_{\mathrm{HV}}$ in time series between the horizontally and vertically polarized radar echoes is useful for determining particle type (Balakrishnan and Zrnic 1990). 


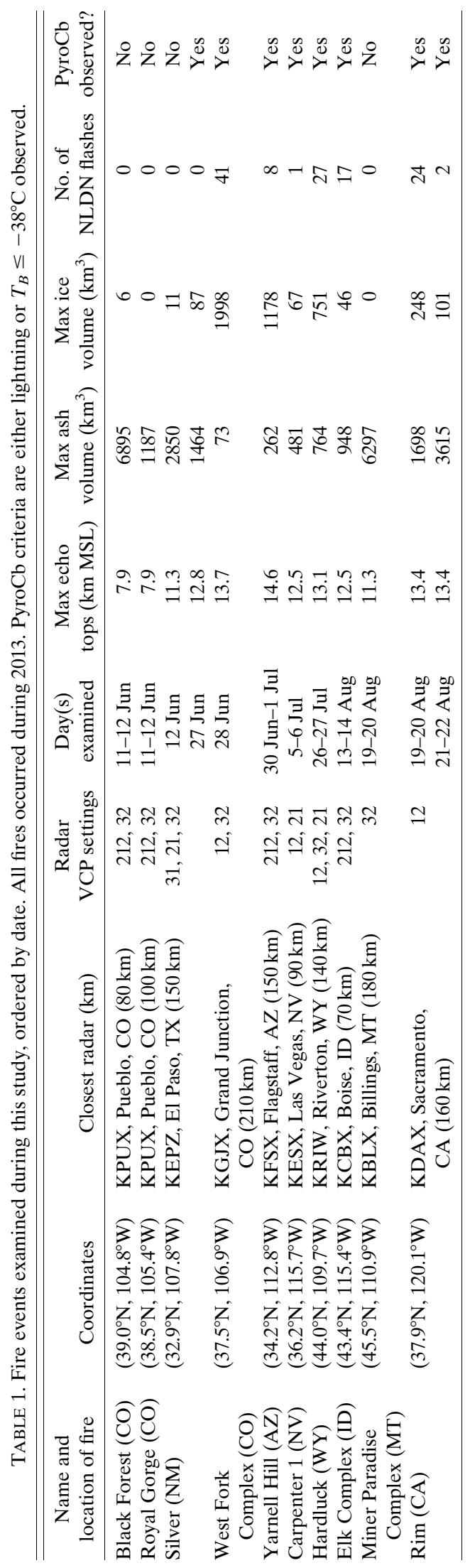

The radar and lightning data were analyzed using Python scripts developed by the authors and the Python Atmospheric Radiation Measurement (ARM) Radar Toolkit (Py-ART; Helmus and Collis 2016).

Time series analyses of ice and ash volumes were created. This was to test whether lightning production is (as expected) more closely linked to ice volumes (i.e., reflecting microphysical processes within thunderstorms) rather than ash volumes (i.e., to rule out triboelectric charging of ash as a major contributor to PyroCb electrification). First the radar volume was narrowed down to a specific area of interest, focused on the ash plume and/or PyroCu cloud near a particular fire. Then a combination of $Z_{\mathrm{H}}, Z_{\mathrm{DR}}$, and $\rho_{\mathrm{HV}}$ values that most likely indicate rimed ice and a separate set that most likely indicate ash were used to identify these particles (Table 2). Temperature data from a nearby sounding were used to help discriminate ice from liquid precipitation.

Table 2 is not based on observations validated with in situ data, and is intended for relative comparisons between radar volumes for an individual PyroCu case, as well as between different cases. The goal is to efficiently identify regions likely containing rimed ice (possibly mixed with ash) and then compare them against regions likely containing pure ash, so that general volumetric trends can be inferred. Table 2 is in part based on the study of Lang et al. (2014), which found that ash and rimed ice mixtures often showed slightly reduced $\rho_{\mathrm{HV}}$ (as low as 0.8 ) as well as noisy $( \pm 1 \mathrm{~dB})$ but near 0 - $\mathrm{dB}$ $Z_{\mathrm{DR}}$. Lang et al. (2014) found that pure ash often featured very low $\rho_{\mathrm{HV}}(<0.8)$, and noisy but predominantly positive $Z_{\mathrm{DR}}(>1 \mathrm{~dB})$. Using a more sophisticated particle identification scheme that included ash, perhaps based on fuzzy logic (Tessendorf et al. 2005; Dolan et al. 2013), was outside the scope of this study, based on its narrow goals (see section 1 ).

Ice (ash) volume was calculated for each relevant range gate in native spherical coordinates using

$$
V_{m}=\pi\left(\frac{r \theta}{2}\right)^{2}\left(\frac{h}{2}\right)
$$

where $r$ is the range to a given gate, $\theta$ is the radar's beamwidth in radians, and $h$ is the gate length in meters (Battan 1973). The volumes of all individual ice (ash) gates were summed up over each radar volume scan to find the total volumes for both categories (ice vs ash), focusing only on the area of interest. The latter was determined manually by drawing a box around the entire ash plume, inclusive of any pyro-convection. However, if other non-pyro-thunderstorms were in the area (which was true for West Fork, Yarnell Hill, and the 
TABLE 2. List of radar parameter values used for determining if the radar was detecting ice or ash in a particular range resolution volume (after Lang et al. 2014).

\begin{tabular}{cccc}
\hline \hline & Parameter & Parameter min value & Parameter max value \\
\hline Ice & $Z_{\mathrm{H}}(\mathrm{dB} Z)$ & $\geq 20$ & $<70$ \\
& $Z_{\mathrm{DR}}(\mathrm{dB})$ & $\geq-1$ & $\leq 1$ \\
& $\rho_{\mathrm{HV}}$ & $\geq 0.8$ & $\leq 1.1$ \\
& $T\left({ }^{\circ} \mathrm{C}\right)$ & & $\leq 0$ \\
Ash & $Z_{\mathrm{H}}(\mathrm{dB} Z)$ & $\geq 0$ & $<30$ \\
& $Z_{\mathrm{DR}}(\mathrm{dB})$ & $>1$ & $\leq 8$ \\
& $\rho_{\mathrm{HV}}$ & $\geq 0$ & $<0.8$ \\
\hline
\end{tabular}

Rim fires), the box was drawn to only focus on the cell closest the main ash plume. Time series were then constructed by examining successive radar volume scans. NLDN data were similarly subsectioned by region of interest and radar volume time.

Because the volumetric analysis was performed in native spherical coordinates, in which vertical gaps can exist between successive radar tilts, this may underestimate the actual ice/ash volumes present at a given time. Interpolation to a grid was not performed out of concern for washing out the often subtle polarimetric signals that occur in mixed ice/ash. However, because the quantitative relationship between precipitationsized rimed ice and lightning is among the strongest and most robust observed in atmospheric science (Williams 2001; Takahashi and Miyawaki 2002; Petersen et al. 2005; Wiens et al. 2005; Deierling et al. 2008), such a relationship should manifest itself clearly and independently of the analysis approach. That is, if this relationship (as expected) were to hold within the PyroCu analyzed in this study, and the NEXRAD and NLDN data were sensitive enough to adequately characterize ice and lightning in these clouds, then this study's time series approach should be sufficient.

For the purposes of this study, a PyroCb was identified if lightning was found to occur in convection with polarimetrically identified rimed ice closest to the polarimetrically identified ash plume associated with a fire. Alternatively, a PyroCb was identified if lightning was not detected but the GOES-15 longwave infrared (IR; channel 4) brightness temperature $\left(T_{B}\right)$ in the clouds closest to the fire reached $-38^{\circ} \mathrm{C}$ or below. This temperature is associated with the homogeneous freezing of liquid water, a common threshold used in past PyroCb studies (Peterson et al. 2017a).

\section{Results}

A representative lightning-producing case was the Hardluck fire, which started on 17 July 2013 in northwestern Wyoming. The fire consumed mostly timber and burned 24648 acres $\left(\sim 100 \mathrm{~km}^{2}\right.$; Inciweb 2014a). On 26 July 2013, PyroCb clouds were produced as the fire burned approximately half its total acreage in one day (Inciweb 2014c), and 27 flashes were detected by the NLDN over a $\sim 3.5$-h period during this activity. Figure 1 shows a panel of radar images from 0003:56 UTC 27 July, which show both ash and PyroCb clouds. The fire was located in the upper-left corner of each plot, and based on the closest sounding (Riverton, Wyoming) at 0000 UTC 27 July, winds aloft were predominantly from the west-northwest.

The lightning-producing PyroCb clouds corresponded to $Z_{\mathrm{H}}$ signatures around $40 \mathrm{~dB} Z$ (Figs. 1a,b), southeast of the actual fire. The value $Z_{\mathrm{DR}}$ was close to $0 \mathrm{~dB}$ near where lightning was occurring (Figs. $1 \mathrm{c}, \mathrm{d}$ ). The $\rho_{\mathrm{HV}}$ values near the lightning were close to 1 (Figs. 1e,f). The ash plume, corresponding to noisy but mostly positive $Z_{\mathrm{DR}}$ (generally $>1 \mathrm{~dB}$ ) and noisy but low $\rho_{\mathrm{HV}}$ (as low as $0.4-0.5$ ), was closer to the fire with maximum $Z_{\mathrm{H}}$ slightly less than $20 \mathrm{~dB} Z$. Based on the particle identification matrix shown in Table 2, the majority of the volume within the lightning-producing pyrocumulus included ice (Figs. 1g,h). The ice was present at multiple elevations, while ash was mainly confined to lower elevations.

A representative example of lightning-free ash plumes was the Royal Gorge fire, which burned 3218 acres $\left(13.02 \mathrm{~km}^{2}\right)$, including multiple structures, during 11-16 June 2013 (Inciweb 2014b). The majority of the destruction occurred on 11 June (Canterbury 2014). This fire did not appear to produce deep PyroCu clouds and did not produce lightning. Radar data from 2341:54 UTC 11 June (Fig. 2), which was near peak intensity of the ash plume on this major burn day, showed $Z_{\mathrm{H}}$ of 20-30 dBZ near the fire (Figs. 2a,b), which is located in the western edge of the plot where the ash plume starts. Based on the closest sounding (Denver, Colorado) at 0000 UTC 12 June, winds aloft were from the westsouthwest. The $Z_{\mathrm{H}}$ values decreased as the ash plume spread eastward. Values of $Z_{\mathrm{DR}}$ varied but were generally above $1 \mathrm{~dB}$ (Figs. 2c,d). The $\rho_{\mathrm{HV}}$ values were less than 0.8 (Figs. 2e,f). Particle identification did not indicate significant amounts of rimed ice (Figs. 2g,h).

Based on analysis of Figs. 1 and 2, precipitation-sized rimed ice was identified mostly where it was expected based on the polarimetric data (Vivekanandan et al. 1999; Tessendorf et al. 2005; Dolan et al. 2013), while ash identification may be leading to underestimates of total volume, due to the speckled nature of identified range gates. However, most of this speckling was caused by $Z_{\mathrm{H}}$ values falling below $0 \mathrm{dBZ}$, pushing the range gate be unclassified (see Table 2). Thus, ash volume trends do not include weakly reflective portions of the plume (i.e., containing few/small ash particles). 

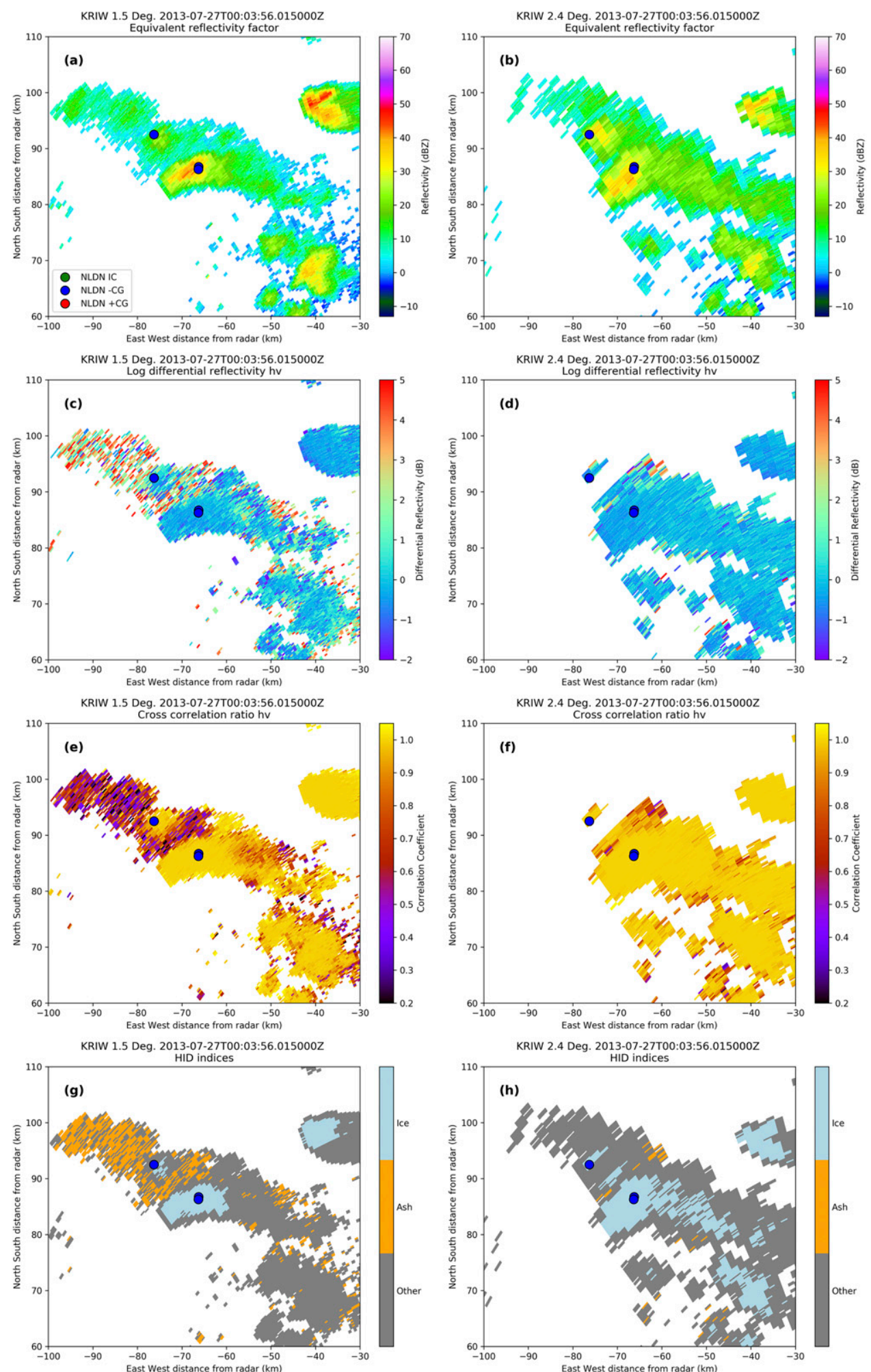

FIG. 1. KRIW PPI imagery for the area of the Hardluck fire at 0003 UTC 27 Jul 2013: (a) $Z_{\mathrm{H}}$ at $1.5^{\circ}$, (b) $Z_{\mathrm{H}}$ at $2.4^{\circ}$, (c) $Z_{\mathrm{DR}}$ at $1.5^{\circ}$, (d) $Z_{\mathrm{DR}}$ at $2.4^{\circ}$, (e) $\rho_{\mathrm{HV}}$ at $1.5^{\circ}$, (f) $\rho_{\mathrm{HV}}$ at $2.4^{\circ}$, (g) ash/ice discrimination at $1.5^{\circ}$, and $(\mathrm{h}) \mathrm{ash} / \mathrm{ice}$ discrimination at $2.4^{\circ}$. The fire is located near $(-100,100)$ for each individual plot, and NLDN flashes during the radar volume are represented as colored dots. Dot color represents either IC or CG, as well as the lightning polarity. 

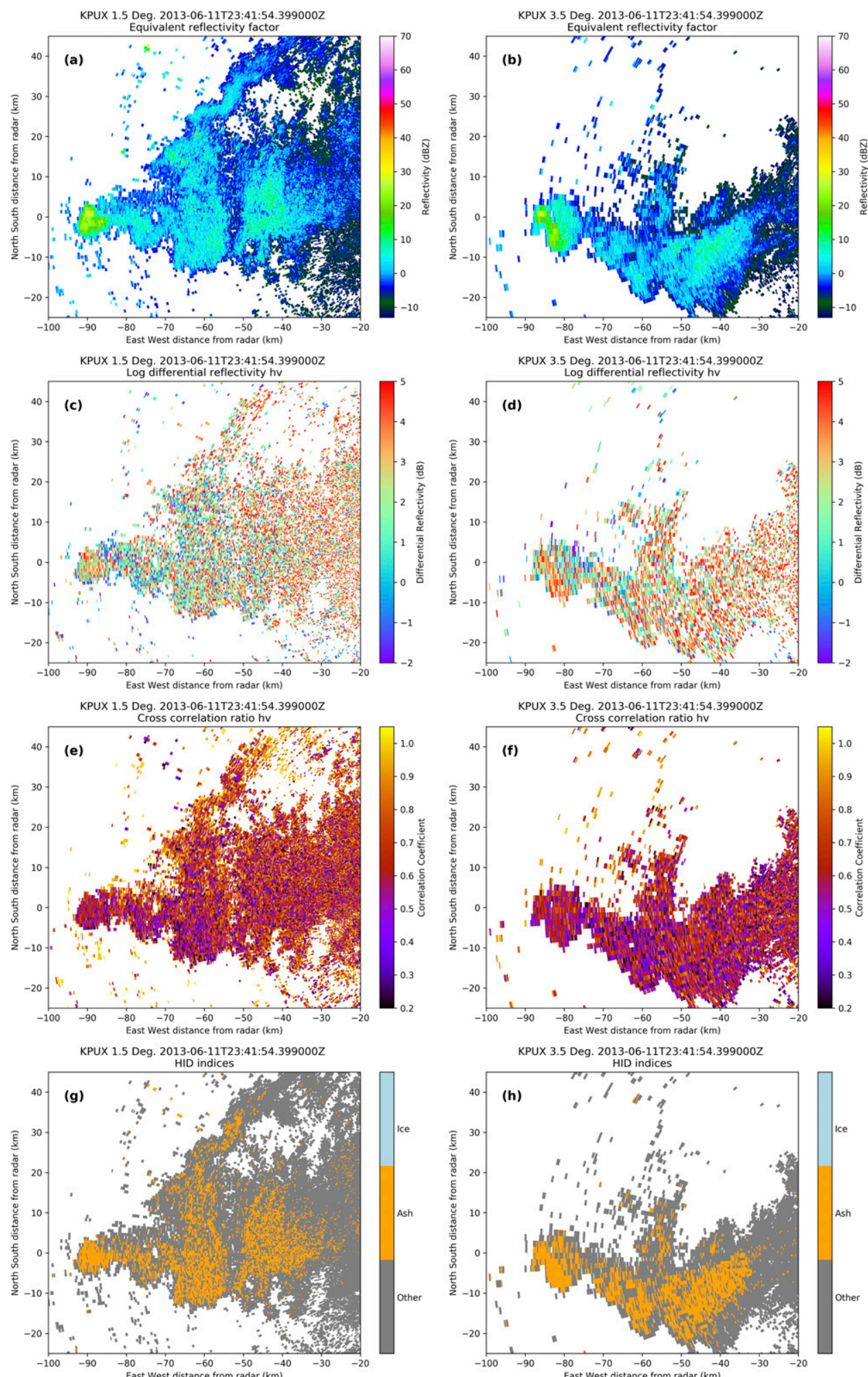

FIG. 2. KPUX PPI imagery for the area of the Royal Gorge fire at $2341 \mathrm{UTC} 11 \mathrm{Jun} 2013:$ (a) $Z_{\mathrm{H}}$ at $1.5^{\circ}$, (b) $Z_{\mathrm{H}}$ at $3.5^{\circ}$, (c) $Z_{\mathrm{DR}}$ at $1.5^{\circ}$, (d) $Z_{\mathrm{DR}}$ at $3.5^{\circ}$, (e) $\rho_{\mathrm{HV}}$ at $1.5^{\circ}$, (f) $\rho_{\mathrm{HV}}$ at $3.5^{\circ}$, (g) ash/ice discrimination at $1.5^{\circ}$, and $(\mathrm{h}) \mathrm{ash} / \mathrm{ice}$ discrimination at $3.5^{\circ}$. The fire is located near $(-90,0)$ for each individual plot, and NLDN flashes during the radar volume are represented as colored dots. Lightning dot color represents either IC or CG, as well as the lightning polarity. 

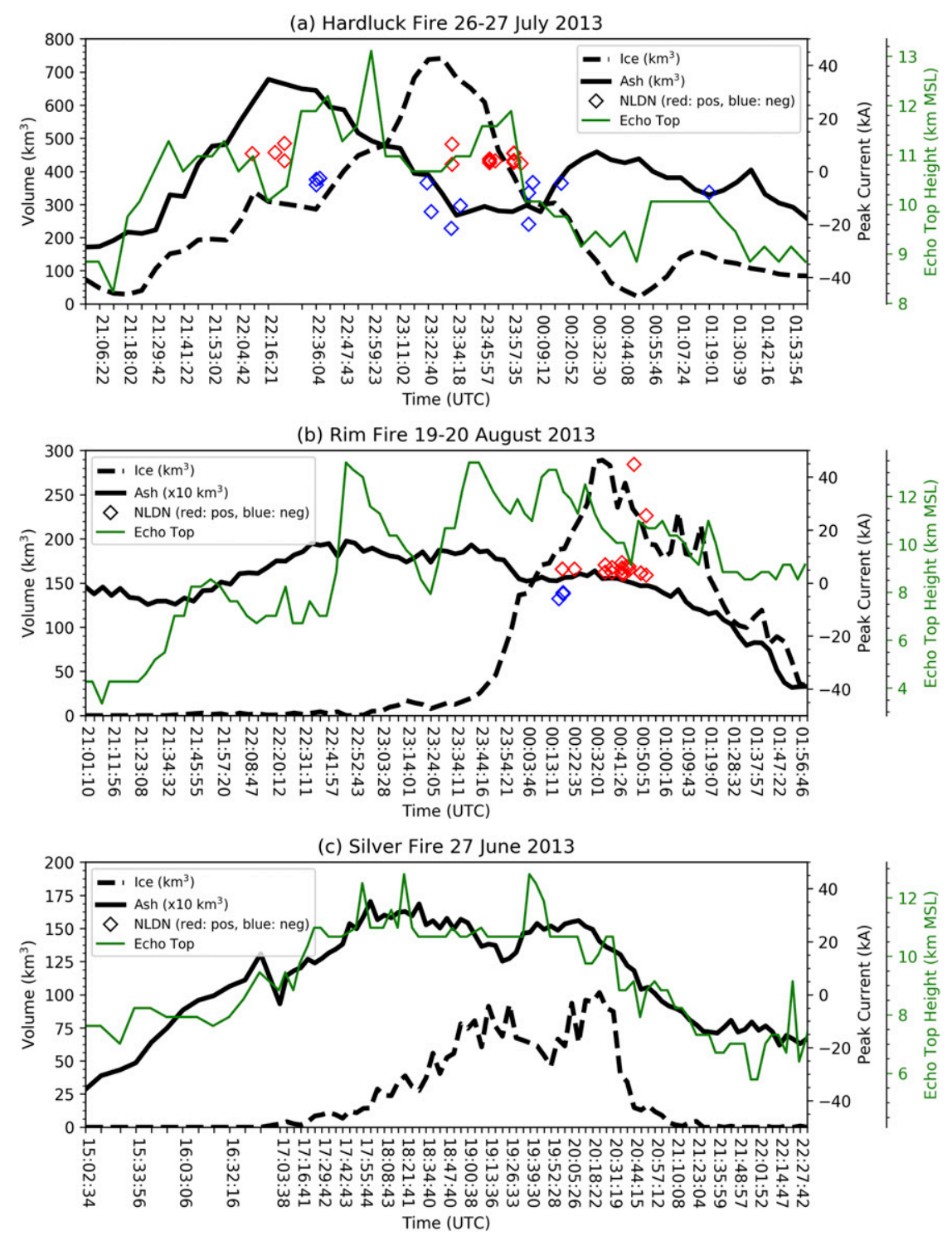

FIG. 3. Time series analysis of total ice volume $\left(\mathrm{km}^{3}\right)$, total ash volume $\left(\mathrm{km}^{3}\right)$, and lightning detections during the (a) Hardluck fire on 26-27 Jul 2013, (b) Rim fire on 19-20 Aug 2013, and (c) Silver fire on 27 Jun 2013. NLDN flashes are separated by polarity and peak current.

The other lightning-producing cases that were examined (West Fork Complex, Yarnell Hill, Carpenter 1, Elk Complex, and Rim; Table 1) featured qualitatively similar observations to Hardluck. That is, they had polarimetric signatures of ice in PyroCb embedded within their ash plumes, particularly during the times they were producing lightning. Meanwhile, other nonlightning cases (Black Forest and Miner Paradise Complex) did not have prevalent ice (nor, for that matter, liquid water) signatures. The Silver fire, to be discussed later, did not produce detected lightning but on one of the analyzed days (27 June) it did produce a PyroCb.
Time series analysis was performed for all cases. Figure 3 shows results for three representative fire cases. All of the cases in Fig. 3 were within 140-160 km of their respective radars, and the radars were in precipitation volume coverage patterns (VCPs; either 12 or 21) during at least part of their respective analysis periods. The Hardluck fire (Fig. 3a) did not produce NLDN-detected lightning until after a relative maximum in ice volume occurred around 2210 UTC 26 July. Echo-top heights reached a relative maximum near $12 \mathrm{~km}$ MSL during this first NLDN burst, but later spiked to the maximum for this case, $13.1 \mathrm{~km}$, near 2300 UTC. Then, a second burst of NLDN flashes occurred 
after ice was maximized around 2320 UTC. Echo-top heights reached a relative maximum near $12 \mathrm{~km}$ MSL during this second lightning burst. A final NLDN flash occurred much later, after a small peak in ice volume near 0115 UTC. While ash volume reached a maximum during the first NLDN burst, the second NLDN burst occurred during a relative ash minimum, suggesting that ash and lightning were not physically related. The lightning consisted of a mix of positive and negative flashes, though most peak currents were confined below $20 \mathrm{kA}$. A number of these flashes consisted of weak $(<10 \mathrm{kA})$ ICs, and the highest peak currents (mainly negative) were not produced until the absolute maximum in ice volume had occurred.

The 19-20 August 2013 case day for the Rim fire (Fig. 3b) was similar, with lightning not occurring until a major increase in ice volume after 0000 UTC 20 August. On this day the Rim fire burned 3530 acres $\left(\sim 14 \mathrm{~km}^{2}\right)$, its largest 1-day total to date (Inciweb 2014d). The majority of the detected lightning consisted of weak $(<10 \mathrm{kA})$ positive ICs, although two positive CGs with higher peak current occurred toward the end of the PyroCb event. Only a few negative flashes occurred and then only at the beginning of the lightning period. Echo tops were variable during the analysis period, periodically reaching the maximum value for this case day $(13.4 \mathrm{~km}$ MSL), but a short-lived relative minimum near $9 \mathrm{~km}$ MSL occurred in the midst of the main NLDN burst. The apparent differences in flash polarities between Hardluck and Rim are interesting, suggesting potentially different charge structures between the two cases. This supports the growing consensus that pyro-clouds can produce a variety of lightning behaviors (Latham 1991; Lyons et al. 1998; Fernandes et al. 2006; Rosenfeld et al. 2007; Lang et al. 2014; Dowdy et al. 2017).

The Silver fire on 27 June 2013 (Fig. 3c) is a good example of a PyroCb cloud that did produce some ice, but no NLDN-detected lightning. On this day the fire burned 11111 acres $\left(\sim 45 \mathrm{~km}^{2}\right.$; Inciweb 2014e). Compared to the previous two cases, even at peak the radar-inferred ice volume $\left(87 \mathrm{~km}^{3}\right)$ was well below the estimates for the Hardluck and Rim fires, despite all fires being similar distances from their respective radars $(\sim 150 \mathrm{~km})$. This observation is consistent with the detection of more lightning in the other pyro-clouds. Whatever the value of max ice volume, all PyroCb clouds in our dataset that produced lightning did so near relative maxima in radar-inferred ice volumes, similar to the cases in Figs. 3a and 3b.

GOES-15 analysis of the four fire cases featured in Figs. 1-3 is shown in Fig. 4. The Hardluck lightning- producing PyroCb (Fig. 4a) also was associated with $T_{B}<-38^{\circ} \mathrm{C}$, particularly downwind of the fire to the east-southeast. GOES-15 analysis confirmed that the lightning-free Royal Gorge (and concurrent Black Forest) fires did not produce cold clouds normally associated with PyroCb (Fig. 4b). The lightning-producing PyroCb for the Rim fire on 19-20 August (Fig. 4c) was part of a large complex of convection in the region. Rim was similar to West Fork and Yarnell Hill in that multiple non-PyroCb thunderstorms were in the vicinity of the PyroCb clouds analyzed in this study. Finally, the 27 June Silver PyroCb (Fig. 4d), though it produced no detected NLDN lightning, was nonetheless associated with $T_{B}<-38^{\circ} \mathrm{C}$.

Returning to Table 1, some basic patterns emerge in the differences between lightning-producing and lightning-free fire cases. Typically, lightning events are associated with higher echo-top heights $(12.5 \mathrm{~km}$ MSL or higher). While ice volume estimates are not easily compared unless the radars were in similar VCPs and at similar distances from the fires (as in Fig. 3), all cases with max ice volume $>100 \mathrm{~km}^{3}$ produced at least some detected lightning. For cases with less ice than this, distance and VCP affected the ambiguity of the volume estimates (e.g., cases closer to the radar or with fewer tilts in their VCPs tended to have reduced ice or ash volumes).

The 27 June Silver case is perhaps the best example of a threshold case in our dataset-no detected lightning, but it produced radar-inferred rimed ice (larger than some lightning-producing cases, though note VCP and distance differences), met the $-38^{\circ} \mathrm{C} T_{B}$ criterion, and also had echo tops to $12.8 \mathrm{~km}$ MSL. It would be unsurprising if this cloud actually produced lightning that was undetected by NLDN.

Because of our PyroCb criteria, there are two discrepancies between our identified PyroCb cases and Peterson et al. (2017a). The 12 June Silver case that Peterson et al. (2017a) labeled a PyroCb did not reach $-38^{\circ} \mathrm{C}$ in our analysis and did not produce detected lightning, though cold cloud with $T_{B}>-38^{\circ} \mathrm{C}$ was present (not shown). Peak radar-inferred ice volumes $\left(11 \mathrm{~km}^{3}\right)$ and echo-top heights (11.3 km MSL) also were low relative to PyroCb cases. This suggests that the 12 June case was marginal and thus its identification as a PyroCb is strongly dependent on parameters and thresholds used. The Carpenter 1 PyroCb on 5-6 July was not identified by Peterson et al. (2017a), but met our criteria due to the single detected NLDN flash it produced (it also reached $T_{B}<-38^{\circ} \mathrm{C}$ ). Here, the added value of NEXRAD and NLDN are demonstrated, since NEXRAD identified significant ice $\left(67 \mathrm{~km}^{3}\right)$ and elevated echo tops (12.5 km MSL) relative to marginal or 
(a) Hardluck 07/26/2013 2356 UTC

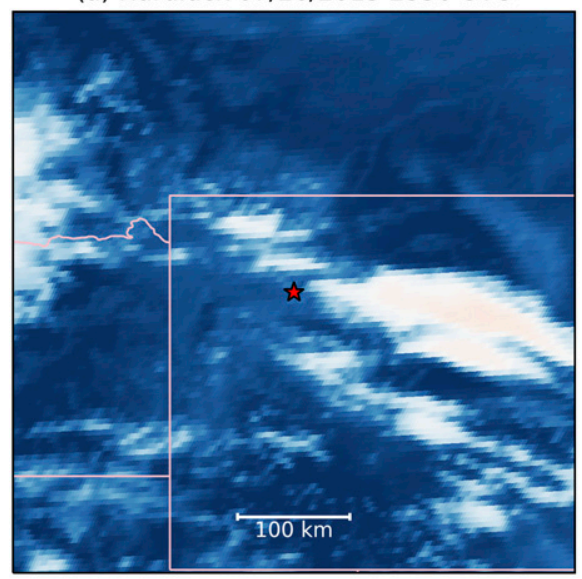

(c) Rim 08/20/2013 0052 UTC

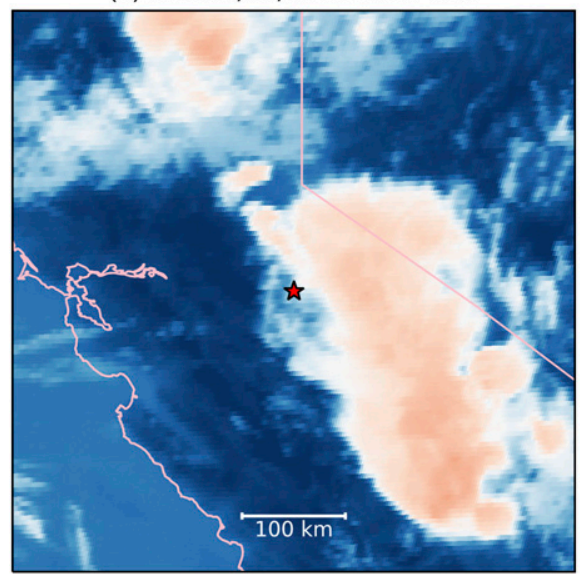

(b) Royal Gorge 06/11/2013 2345 UTC

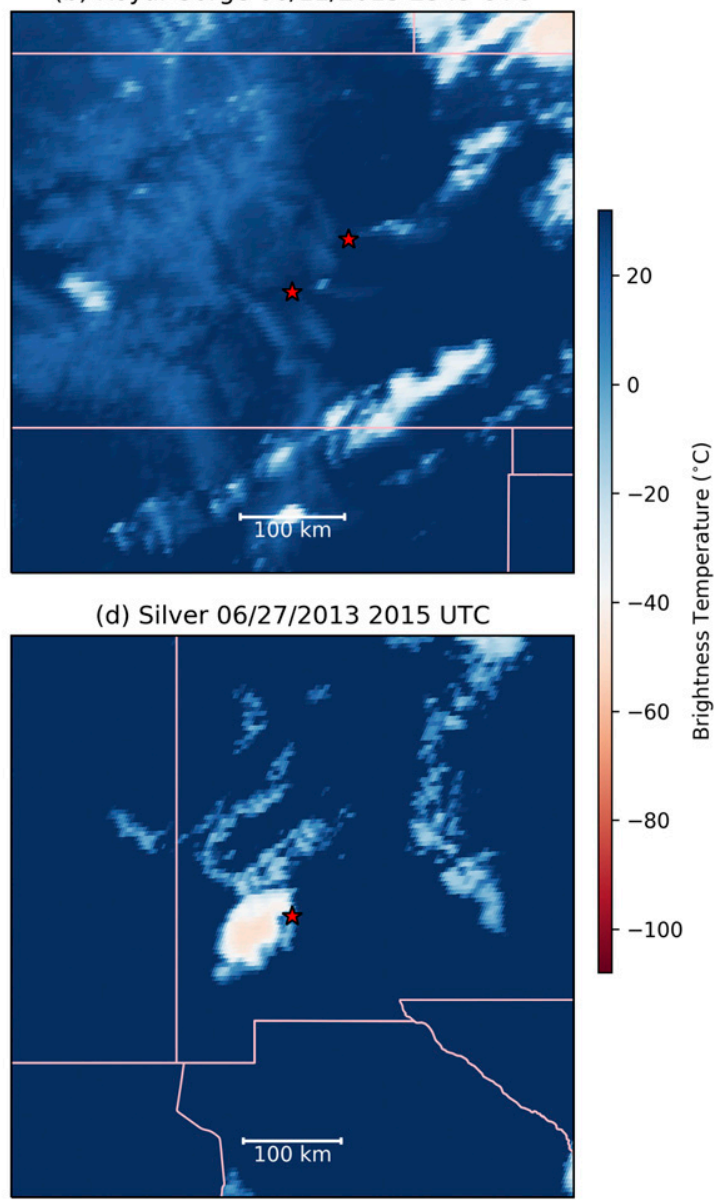

FIG. 4. GOES-15 longwave IR (channel 4) $T_{B}$ for four different fires analyzed in this study. Times shown are either compatible with Figs. 1 and 2 or near-maximum ice volume as shown in Fig. 3. Approximate fire locations are indicated by red stars, and the $T_{B}$ color table is deliberately centered on $-38^{\circ} \mathrm{C}$ (i.e., reds $<-38^{\circ} \mathrm{C}$ ): (a) Hardluck fire, (b) Royal Gorge fire (the northeast star is the Black Forest fire, which burned concurrently), (c) Rim fire, and (d) Silver fire.

null cases like 12 June Silver and the Miner Paradise Complex.

To determine if there were distinctive differences between the environments of lightning-producing and lightning-free events, local soundings were analyzed (with the caveat that most of these locations were $>100 \mathrm{~km}$ from the fire; see Table 1), and the results are summarized in Table 3 . Since the number of cases (12) was low, no statistical tests were performed. Values of most unstable CAPE, CIN, LCL, and TPW overlapped considerably between plumes that produced lightning and those that did not, and frequent lightning producers (e.g., West Fork) did not necessarily have more unstable or moister atmospheres than less frequent lightning producers (e.g., Yarnell Hill). In general, the soundings for all days tended to feature near dry-adiabatic conditions at low levels, along with relatively high LCLs and modest instability. In all but one case TPW was less than $20 \mathrm{~mm}$. That is, the soundings were dry and supportive of active fire behavior, as well as convection in most cases.

\section{Conclusions}

Returning to the scientific questions posited in section 1 , the unusual microphysical and lightning observations of Lang et al. (2014) are also evident in additional PyroCu cases. To wit, embedded ice clouds within ash plumes are capable of producing occasional lightning, in particular weak IC flashes, and the upgraded NEXRAD and NLDN networks are capable of observing and documenting this phenomenon across at least the western United States. 
TABLE 3. Summary of notable sounding parameters for each 2013 wildfire case. Most unstable parcel was used. The analysis package used for these calculations was the Sounding/Hodograph Analysis and Research Program in Python (SHARPpy; Blumberg et al. 2017).

\begin{tabular}{|c|c|c|c|c|c|c|}
\hline Name of fire & Sounding station & Sounding time/date & CAPE $\left(\mathrm{J} \mathrm{kg}^{-1}\right)$ & $\mathrm{CIN}\left(\mathrm{J} \mathrm{kg}^{-1}\right)$ & LCL $(\mathrm{hPa})$ & TPW (mm) \\
\hline Black Forest & Denver, CO & 0000 UTC 12 Jun & 293 & 0 & 423 & 5 \\
\hline Royal Gorge & Denver, $\mathrm{CO}$ & 0000 UTC 12 Jun & 293 & 0 & 423 & 5 \\
\hline \multirow[t]{2}{*}{ Silver } & El Paso, TX & 0000 UTC 13 Jun & 676 & 0 & 519 & 16 \\
\hline & & 0000 UTC 28 Jun & 66 & 0 & 476 & 10 \\
\hline West Fork Complex & Grand Junction, CO & 0000 UTC 29 Jun & 324 & 0 & 485 & 12 \\
\hline Yarnell Hill & Flagstaff, AZ & 0000 UTC 1 Jul & 775 & 27 & 536 & 14 \\
\hline Carpenter 1 & Las Vegas, NV & 0000 UTC 5 Jul & 458 & 1 & 567 & 17 \\
\hline Hardluck & Riverton, WY & 0000 UTC $27 \mathrm{Jul}$ & 578 & 0 & 544 & 12 \\
\hline Elk Complex & Boise, ID & 0000 UTC 14 Aug & 796 & 0 & 599 & 14 \\
\hline Miner Paradise Complex & Great Falls, MT & 0000 UTC 20 Aug & 1 & 75 & 561 & 13 \\
\hline \multirow[t]{2}{*}{$\operatorname{Rim}$} & Reno, NV & 0000 UTC 20 Aug & 262 & 24 & 633 & 24 \\
\hline & & 0000 UTC 22 Aug & 552 & 37 & 633 & 18 \\
\hline
\end{tabular}

Specifically, polarimetric NEXRAD is useful for distinguishing between regions of ice and ash, even when using a simplified particle identification matrix. Indeed, NEXRAD observations at ranges beyond $100 \mathrm{~km}$ (suggesting degraded data quality) are still adequate for making scientifically useful interpretations about microphysical structures of ash plumes and pyroclouds. Meanwhile, the more sensitive NLDN is capable of detecting at least some weak $(<10 \mathrm{kA})$ IC flashes, which commonly occur in pyro-clouds (Lang et al. 2014). While it is unclear whether the NLDN detects these flashes at the $50 \%$ rate that is reported for all ICs, they correspond well to relative maxima and minima observed in precipitation-sized rimed ice inferred by NEXRADs (e.g., Fig. 3). In other words, the NLDN now detects pyro-lightning at a rate that is high enough to make scientific comparisons with independent datasets. This is a significant improvement over the preupgrade NLDN dataset analyzed by Lang et al. (2014). The upgraded NEXRAD and NLDN datasets also provide a useful complement to geostationary visible and IR analysis of PyroCb clouds, and are useful for identifying lightning-producing PyroCb (e.g., 5-6 July Carpenter 1) missed by previous satellite-based census studies (Peterson et al. 2017a).

Future PyroCu research should take advantage of the recent launch of GOES-16, equipped with the highresolution Advanced Baseline Imager (ABI; Schmit et al. 2005) and the Geostationary Lightning Mapper (GLM; Goodman et al. 2013), as these datasets are expected to provide highly complementary information on cloud and electrical behaviors, when used in concert with the NEXRAD and NLDN data. For example, similar to NLDN, GLM is expected to detect a significant fraction of pyro-cloud lightning (48\%-100\%, depending on case), based on prelaunch analysis by Lang et al. (2015).
These datasets are hypothesized to be able to show direct and indirect relationships between $\mathrm{PyroCu}$ structure and evolution, lightning production, and fire intensity (Lang et al. 2014). Such patterns could be used to indicate when a wildfire is undergoing rapid intensification, or indicate a need to change nearby radar scanning to provide better vertical coverage.

Acknowledgments. The authors are grateful for discussions with Bryan Baum and Scott Bachmeier about many of the cases analyzed in this study. Comments from three reviewers were greatly appreciated and improved the quality of the study. NLDN data were obtained from Vaisala, Inc. via the Global Hydrology Resource Center (GHRC) Distributed Active Archive Center (DAAC; https://ghrc.nsstc.nasa.gov/home/). NEXRAD data were obtained from NOAA via Amazon Web Services (https://aws.amazon.com/noaa-bigdata/nexrad/). GOES-15 data were obtained from the NOAA Comprehensive Large Array-Data Stewardship System (CLASS; https://www.class.ngdc.noaa. gov). Discussions of several of the fires examined in this study may be found at http://pyrocb.ssec.wisc. edu/ and https://inciweb.nwcg.gov/. Sounding data may be obtained from http://weather.uwyo.edu/upperair/ sounding.html. The Py-ART software may be obtained from https://github.com/ARM-DOE/pyart. Specialized Python analysis scripts may be requested from the corresponding author. Support for this research came from the NASA Science Innovation Fund, the Defense Advanced Research Projects Agency (DARPA) Nimbus program, the NASA Internship program, and the NASA Lightning Imaging Sensor project. The views, opinions, and findings in this report are those of the authors, and should not be construed as an official NASA or U.S. government position, policy, or decision. 


\section{REFERENCES}

Balakrishnan, N., and D. S. Zrnic, 1990: Use of polarization to characterize precipitation and discriminate large hail. J. Atmos. Sci., 47, 1525-1540, https://doi.org/10.1175/1520 0469(1990)047<1525:UOPTCP > 2.0.CO;2.

Battan, L. J., 1973: Radar Observation of the Atmosphere. The University of Chicago Press, $324 \mathrm{pp}$.

Biagi, C. J., K. L. Cummins, K. E. Kehoe, and E. P. Krider, 2007: National Lightning Detection Network (NLDN) performance in southern Arizona, Texas, and Oklahoma in 2003-2004. J. Geophys. Res., 112, D05208, https://doi.org/10.1029/ 2006JD007341.

Blumberg, W. G., K. T. Halbert, T. A. Supinie, P. T. Marsh, R. L. Thompson, and J. A. Hart, 2017: SHARPpy: An Open-Source Sounding Analysis Toolkit for the Atmospheric Sciences. Bull. Amer. Meteor. Soc., 98, 1625-1636, https://doi.org/ 10.1175/BAMS-D-15-00309.1.

Canterbury, C., 2014: Looking back at the Royal Gorge Fire, one year later. Daily Record, Canon City News, 7 June 2014, http://www. canoncitydailyrecord.com/news/canoncity-local-news/ci_25914616/ looking-back-at-royal-gorge-fire-one-year.

Cummins, K. L., and M. J. Murphy, 2009: An overview of lightning location systems: History, techniques, and data uses, with an in-depth look at the U.S. NLDN. IEEE Trans. Electromag. Compat., 51, 499-518, https://doi.org/10.1109/ TEMC.2009.2023450

Cunha, L. K., J. A. Smith, W. F. Krajewski, M. L. Baeck, and B. Seo, 2015: NEXRAD NWS polarimetric precipitation product evaluation for IFloodS. J. Hydrometeor., 16, 16761699, https://doi.org/10.1175/JHM-D-14-0148.1.

Deierling, W., W. A. Petersen, J. Latham, S. Ellis, and H. J. Christian, 2008: The relationship between lightning activity and ice fluxes in thunderstorms. J. Geophys. Res., 113, D15210, https://doi.org/10.1029/2007JD009700.

Dolan, B., S. A. Rutledge, S. Lim, V. Chandrasekar, and M. Thurai, 2013: A robust C-band hydrometeor identification algorithm and application to a long-term polarimetric radar dataset. J. Appl. Meteor. Climatol., 52, 2162-2186, https://doi.org/ 10.1175/JAMC-D-12-0275.1

Dowdy, A. J., M. D. Fromm, and N. McCarthy, 2017: Pyrocumulonimbus lightning and fire ignition on Black Saturday in southeast Australia. J. Geophys. Res. Atmos., 122, 7342-7354, https://doi.org/10.1002/2017JD026577.

Fernandes, W. A., I. R. Pinto, O. Pinto, K. M. Longo, and S. R. Freitas, 2006: New findings about the influence of smoke from fires on the cloud-to-ground lightning characteristics in the Amazon region. Geophys. Res. Lett., 33, L20810, https://doi.org/ 10.1029/2006GL027744.

Fromm, M., R. Bevilacqua, R. Servranckx, J. Rosen, J. P. Thayer, J. Herman, and D. Larko, 2005: Pyro-cumulonimbus injection of smoke to the stratosphere: Observations and impact of a super blowup in northwestern Canada on 3-4 August 1998. J. Geophys. Res., 110, D08205, https://doi.org/10.1029/2004JD005350.

- D. T. Lindsey, R. Servranckx, G. Yue, T. Trickl, R. Sica, P. Doucet, and S. Godin-Beekmann, 2010: The untold story of pyrocumulonimbus. Bull. Amer. Meteor. Soc., 91, 1193-1209, https://doi.org/10.1175/2010BAMS3004.1.

Goodman, S. J., and Coauthors, 2013: The GOES-R Geostationary Lightning Mapper (GLM). Atmos. Res., 125-126, 34-49, https://doi.org/10.1016/j.atmosres.2013.01.006.

Helmus, J. J., and S. M. Collis, 2016: The Python ARM Radar Toolkit (Py-ART): A library for working with weather radar data in the Python programming language. J. Open Res. Software, 4, e25, https://doi.org/10.5334/jors.119.

Inciweb, 2014a: Hardluck fire. Shoshone National Forest, U.S. Forest Service, WY, accessed 1 July 2014, http:/inciweb.nwcg.gov/ incident $/ 3546 /$.

— , 2014b: Royal Gorge fire. Royal Gorge Field Office, Bureau of Land Management, CO, accessed 1 July 2014, http://inciweb. nwcg.gov/incident $/ 3419 /$.

_, 2014c: Hardluck fire progression map July 28, 2013. Shoshone National Forest, U.S. Forest Service, accessed 1 July 2014, https://inciweb.nwcg.gov/incident/map/3546/16/31489/.

_ , 2014d: Rim fire progression map, August 31, 2013. Stanislaus National Forest, U.S. Forest Service, accessed 1 July 2014, https://inciweb.nwcg.gov/incident/map/3660/45/34774/.

2014e: Silver fire IR progression map 6-28-13. Gila National Forest, U.S. Forest Service, accessed 1 July 2014, https:// inciweb.nwcg.gov/incident/map/3414/6/30326/.

Johnson, R. H., R. S. Schumacher, J. H. Ruppert, D. T. Lindsey, J. E. Ruthford, and L. Kriederman, 2014: The role of convective outflow in the Waldo Canyon fire. Mon. Wea. Rev., 142, 3061-3080, https://doi.org/10.1175/MWR-D-13-00361.1.

Jones, T. A., S. A. Christopher, and W. Petersen, 2009: Dual-polarization radar characteristics of an apartment fire. J. Atmos. Oceanic Technol., 26, 2257-2269, https://doi.org/10.1175/ 2009JTECHA1290.1

Lang, T. J., and S. A. Rutledge, 2002: Relationships between convective storm kinematics, precipitation, and lightning. Mon. Wea. Rev., 130, 2492-2506, https://doi.org/10.1175/15200493(2002)130<2492:RBCSKP > 2.0.CO;2.

,$-\longrightarrow$, B. Dolan, P. Krehbiel, W. Rison, and D. T. Lindsey, 2014: Lightning in wildfire smoke plumes observed in Colorado during summer 2012. Mon. Wea. Rev., 142, 489-507, https://doi.org/10.1175/MWR-D-13-00184.1.

_ , K. Laroche, B. Baum, M. Bateman, and D. Mach, 2015: Investigation of the electrification of pyrocumulus clouds. Seventh Conf. on the Meteorological Applications of Lightning Data, Phoenix, AZ, Amer. Meteor. Soc., 6.5, https://ams.confex.com/ ams/95Annual/webprogram/Paper262792.html.

Lareau, N. P., and C. B. Clements, 2016: Environmental controls on pyrocumulus and pyrocumulonimbus initiation and development. Atmos. Chem. Phys., 16, 4005-4022, https://doi.org/ 10.5194/acp-16-4005-2016.

Latham, D. J., 1991: Lightning flashes from a prescribed fireinduced cloud. J. Geophys. Res., 96, 17151-17157, https:// doi.org/10.1029/91JD01808

Lyons, W. A., T. E. Nelson, E. R. Williams, J. A. Cramer, and T. R. Turner, 1998: Enhanced positive cloud-to-ground lightning in thunderstorms ingesting smoke from fires. Science, 282, 77-80, https://doi.org/10.1126/science.282.5386.77.

Mansell, E. R., and C. L. Ziegler, 2013: Aerosol effects on simulated storm electrification and precipitation in a two-moment bulk microphysics model. J. Atmos. Sci., 70, 2032-2050, https:// doi.org/10.1175/JAS-D-12-0264.1.

Mattos, E. V., L. A. T. Machado, E. R. Williams, S. J. Goodman, R. J. Blakeslee, and J. C. Bailey, 2017: Electrification life cycle of incipient thunderstorms. J. Geophys. Res. Atmos., 122, 4670-4697, https://doi.org/10.1002/2016JD025772.

Melnikov, V. M., D. S. Zrnić, R. M. Rabin, and P. Zhang, 2008: Radar polarimetric signatures of fire plumes in Oklahoma. Geophys. Res. Lett., 35, L14815, https://doi.org/10.1029/2008GL034311.

- - - , and,- 2009: Polarimetric radar properties of smoke plumes: A model. J. Geophys. Res., 114, D21204, https://doi.org/10.1029/2009JD012647. 
Murphy, M. J., and A. Nag, 2015: Cloud lightning performance and climatology of the U.S. based on the upgraded U.S. National Lightning Detection Network. Seventh Conf. on the Meteorological Applications of Lightning Data, Phoenix, AZ, Amer. Meteor. Soc., 8.2, https://ams.confex.com/ams/95Annual/webprogram/ Manuscript/Paper262391/AMS2015_MALD_8.2_murphy.pdf.

Orville, R. E., and A. C. Silver, 1997: Lightning ground flash density in the contiguous United States: 1992-95. Mon. Wea. Rev., 125, 631-638, https://doi.org/10.1175/1520-0493(1997)125<0631: LGFDIT > 2.0.CO;2.

Peterson, D. A., M. D. Fromm, J. E. Solbrig, E. J. Hyer, M. L. Surratt, and J. R. Campbell, 2017a: Detection and inventory of intense pyroconvection in western North America using GOES-15 daytime infrared data. J. Appl. Meteor. Climatol., 56, 471-493, https:// doi.org/10.1175/JAMC-D-16-0226.1.

, E. J. Hyer, J. R. Campbell, J. E. Solbrig, and M. D. Fromm, 2017b: A conceptual model for development of intense pyrocumulonimbus in western North America. Mon. Wea. Rev., 145, 2235-2255, https://doi.org/10.1175/MWR-D-16-0232.1.

Petersen, W. A., H. J. Christian, and S. A. Rutledge, 2005: TRMM observations of the global relationship between ice water content and lightning. Geophys. Res. Lett., 32, L14819, https:// doi.org/10.1029/2005GL023236.

Reutter, P., and Coauthors, 2014: 3-D model simulations of dynamical and microphysical interactions in pyroconvective clouds under idealized conditions. Atmos. Chem. Phys., 14, 7573-7583, https://doi.org/10.5194/acp-14-7573-2014.

Rinehart, R. E., 2010: Radar for Meteorologists. 5th ed. Rinehart Publications, $482 \mathrm{pp}$.

Rosenfeld, D., M. Fromm, J. Trentmann, G. Luderer, M. O. Andreae, and R. Servranckx, 2007: The Chisholm firestorm: Observed microstructure, precipitation and lightning activity of a pyro-cumulonimbus. Atmos. Chem. Phys., 7, 645-659, https://doi.org/10.5194/acp-7-645-2007.
Schmit, T. J., M. M. Gunshor, W. P. Menzel, J. J. Gurka, J. Li, and A. S. Bachmeier, 2005: Introducing the next-generation advanced baseline imager on GOES-R. Bull. Amer. Meteor. Soc., 86, 1079-1096, https://doi.org/10.1175/BAMS-86-8-1079.

Smith, J. A., D. J. Seo, M. L. Baeck, and M. D. Hudlow, 1996: An intercomparison study of NEXRAD precipitation estimates. Water Resour. Res., 32, 2035-2045, https://doi.org/10.1029/ 96WR00270.

Smith, P. L., 1984: Equivalent radar reflectivity factors for snow and ice particles. J. Climate Appl. Meteor., 23, 1258-1260, https://doi.org/ 10.1175/1520-0450(1984)023<1258:ERRFFS > 2.0.CO;2.

Takahashi, T., 1978: Riming electrification as a charge generation mechanism in thunderstorms. J. Atmos. Sci., 35 , 1536-1548, https://doi.org/10.1175/1520-0469(1978)035<1536: REAACG $>2.0 . \mathrm{CO} ; 2$.

— and K. Miyawaki, 2002: Reexamination of riming electrification in a wind tunnel. J. Atmos. Sci., 59, 1018-1025, https://doi.org/ 10.1175/1520-0469(2002)059<1018:ROREIA > 2.0.CO;2.

Tessendorf, S. A., L. J. Miller, K. C. Wiens, and S. A. Rutledge, 2005: The 29 June 2000 supercell observed during STEPS. Part I: Kinematics and microphysics. J. Atmos. Sci., 62, 4127-4150, https://doi.org/10.1175/JAS3585.1.

Vivekanandan, J., S. M. Ellis, R. Oye, D. S. Zrnić, A. V. Ryzhkov, and J. Straka, 1999: Cloud microphysics retrieval using S-band dual-polarization radar measurements. Bull. Amer. Meteor. Soc., 80, 381-388, https://doi.org/10.1175/1520-0477(1999)080<0381: CMRUSB $>2.0$. CO;2.

Wiens, K. C., S. A. Rutledge, and S. A. Tessendorf, 2005: The 29 June 2000 supercell observed during STEPS. Part II: Lightning and charge structure. J. Atmos. Sci., 62, 4151-4177, https://doi.org/10.1175/JAS3615.1.

Williams, E. R., 2001: The electrification of severe storms. Severe Convective Storms, Meteor. Monogr., No. 49, Amer. Meteor. Soc., 527-561. 